\title{
Concept Expansion as a Source of Empowerment
}

\section{Citation}

Cikara, Mina. 2016. “Concept Expansion as a Source of Empowerment." Psychological Inquiry 27 (1) (January 2): 29-33. doi:10.1080/1047840x.2016.1111830.

\section{Published Version}

doi:10.1080/1047840X.2016.1111830

\section{Permanent link}

http://nrs.harvard.edu/urn-3:HUL.InstRepos:32197088

\section{Terms of Use}

This article was downloaded from Harvard University's DASH repository, and is made available under the terms and conditions applicable to Open Access Policy Articles, as set forth at http:// nrs.harvard.edu/urn-3:HUL.InstRepos:dash.current.terms-of-use\#OAP

\section{Share Your Story}

The Harvard community has made this article openly available.

Please share how this access benefits you. Submit a story.

Accessibility 


\section{Concept Expansion as a Source of Empowerment}

In the target article, Haslam explores the incidence, origins, and potential consequences of concept creep in psychology. He dedicates the majority of the article to documenting how concept creep has manifested in six psychological concepts: abuse, bullying, trauma, mental disorder, addiction, and prejudice. Haslam convincingly demonstrates that these concepts have indeed expanded over time to include both qualitatively different and less severe forms of each concept. I agree whole-heartedly with Haslam when he says: "Understanding what drives this trend and evaluating its costs and benefits are important goals for people who care about psychology's place in our cultures. Equally important is the task of deciding whether the trend should be encouraged, ignored, or resisted."

Throughout the article, Haslam is careful to avoid normative claims regarding creep's costs and benefits with regard to any one of the concepts in isolation. Regarding prejudice, for example, he notes: "It is important to reiterate here that by documenting the expanding meaning of prejudice in recent social psychology I am not questioning the validity of this expansion or advocating a return to a narrower understanding of the concept...My point is simply that the concept now refers to much more than it did several decades ago." However, Haslam does state that as a general phenomenon, concept creep may "have potentially damaging ramifications for society and for psychology that cannot be ignored." Specifically, he suggests that concept creep may cause more people to identify as victims, which may reduce their sense of agency. Drawing on 'moral typecasting' theory (Gray \& Wegner, 2009), he states: "A possible adverse looping effect of concept creep is therefore a tendency for more and more people to see themselves as victims who are defined by their suffering, vulnerability, and innocence, and who have diminished agency to overcome their plight."

The goal of this commentary is to challenge this last suggestion. Focusing on concept creep as it relates to prejudice and discrimination, I highlight three mechanisms by which conceptual expansion may actually serve to empower "victims," interaction partners, and $3^{\text {rd }}$ party allies. (It is worth noting that several of these mechanisms could generalize to the other concepts highlighted in the target article.) First, labeling less qualitatively and quantitatively prototypical instances of prejudice as prejudice may reduce targets' uncertainty about their experiences. Thus, rather than diminishing agency, concept expansion may dampen diffuse negative arousal, reduce an avoidance orientation to intergroup interactions, and inspire greater engagement in collective action on behalf of one's group. Second, these labels may serve to reduce uncertainty among well-meaning interaction partners and $3^{\text {rd }}$-parties, fostering stronger alliances in the long term between disadvantaged and advantaged individuals and groups. Finally, concept expansion may open up institutional channels for redressing social ills and inequalities that would remain closed if less prototypical manifestations of prejudice were considered categorically distinct.

\section{Labels reduce uncertainty and associated affect}

Uncertainty is inherently aversive especially when it relates to the self and other people (Lopes, 1987; Sorrentino \& Roney, 1986). It is associated with physiological arousal in the hypothalamic-pituitary-adrenal (HPA) axis of the brain (Greco \& Roger, 
2003), is often accompanied by diffuse negative affect and anxiety (Gudykunst, 1995), and in social interactions, leads to misunderstanding and attribution of negative intent (Cohen \& Steele, 2002; Devine \& Vasquez, 1998; Kramer \& Wei, 1999; Morewedge, 2009; Stephan \& Stephan, 1985). As such, uncertainty is a strong motivator of behavior. People act to reduce uncertainty (Festinger,1954; Fromm, 1947; Hogg, 2007) and avoid situations that are uncertainty-inducing (e.g., Camerer \& Weber, 1992).

One strategy for reducing uncertainty is labeling or identifying the cause of an event (Pennebaker \& Graybeal, 2001). Increased certainty, in turn, diminishes both positive and negative affective states across a wide variety of contexts (Bar-Anan, Wilson, \& Gilbert, 2009; Davis, Nolen-Hoeksema, \& Larson, 1998; Wilson \& Gilbert, 2008). For example, people who are prompted to write about negative events in their lives report greater well-being (Pennebaker, 1997). This phenomenon is best illustrated by the research on affect-labeling. Simply labeling emotions as they arise decreases both physiological reactivity associated with those emotions (Berkman \& Lieberman, 2009) as well as the self-reported intensity of said emotions (Lieberman, Inagaki, Tabibnia, \& Crockett, 2011); the effects of affect-labeling have been shown to last up to a week (Tabibnia, Lieberman, \& Craske, 2008).

Because labels can be qualified, people can reap the benefits (e.g., uncertaintyreduction) of labeling events without invoking the most severe or prototypical instance of that label. Hence the qualification in "micro-aggressions." Furthermore, people can recognize not only that an experience belongs to a certain class or category, but also that any specific instance can be relatively more or less severe without corrupting the other members of said category. For example, most people would be happy to label cerulean as "blue"; however, labeling cerulean as blue would not make people any less likely to say that navy is also blue. In sum, labels may promote positive hedonic consequences without necessarily producing what Haslam calls "semantic dilution."

\section{Empowering targets of prejudice}

Being the target of overt prejudice is associated with many threats to psychological well-being (e.g., Crocker, Major, \& Steele, 1998; Tropp, 2003). As Haslam notes, however, overt bigotry has in recent decades been replaced with more subtle (but no less insidious) forms of prejudice and discrimination (Bonilla-Silva \& Dietrich, 2011). Potential targets now have to contend not only with the effects of being discriminated against but also the ambiguity of whether a gesture or policy is intentionally biased against them. As noted, uncertainty may exacerbate the emotional responses triggered by these episodes (Bar-Anan et al., 2009), but may also undermine a target's subjective sense of legitimacy in addressing potential bias (Ellemers \& Barreto, 2009).

People assess the validity of their perceptions by comparing their experiences and abilities with others (Suls \& Wheeler, 2000). Labels allow for the validation of one's experiences via communication with other people who have had similar experiences. Validation from others, in turn, reduces uncertainty (Berger, 1987; Berger \& Calabrese, 1975; Bradac, 2001). Thus, labeling subtle forms of prejudice as prejudice may reduce uncertainty both within and between individuals, which in turn, reduces diffuse negative arousal. This is not to say that the prejudice label reduces negative affect globally: for example, in this case anxiety is likely to be replaced with anger. However, the label may 
shift a target of prejudice from an uncertainty avoidance orientation (i.e., "shun further intergroup contact") toward an approach orientation (i.e., "point out perceived injustice"). Though emotions like anger are negative in the short term, they (along with feelings of collective efficacy) are critical for motivating collective action on behalf of one's group (Van Zomeren, Postmes, \& Spears, 2008).

The importance of shifting the emphasis in intergroup relations from prejudicereduction to empowering disadvantaged groups is well supported by recent research (for reviews, see Dixon, Levin, Reicher, \& Durrheim, 2012; Dovidio, Gartner, \& Saguy, 2009, 2015; see also Cikara \& Paluck, 2013). Particularly when groups are of differing status, fostering harmony (e.g., by making common identity salient or cultivating positive intergroup contact) may have the ironic consequence of reinforcing ideological and structural biases that promote the hierarchical status quo. For example, leading two groups in a discussion emphasizing their commonalities (as compared to group differences) leads disadvantaged groups to be more optimistic-and less accurateabout how advantaged groups will split resources between the groups (Saguy, Tausch, Dovidio, \& Pratto, 2008). Interventions and experiences that promote harmony also decrease preferences for social change (Saguy et al., 2008), lead to lower levels of anger, decrease expectations regarding the group's capacity to effect change, and decrease motivation to challenge inequality (Ufkes, Calcagno, Glasford, \& Dovidio, 2013). For example, women's engagement in collective action increases after exposure to overtly hostile sexist attitudes (e.g., the belief that gender relations are antagonistic and that women just want to control men), but decreases after exposure to paternalistic sexist attitudes (e.g., the belief that women and men should collude in the interest of the protection and adulation of women who conform to traditional female stereotypes; Becker \& Wright, 2011).

Thus, it seems that some degree of conflict is required for social progress in inequitable intergroup contexts (Dovidio et al., 2009). Rather than chipping away at targets' agency, labeling less prototypical forms of prejudice as prejudice may trigger emotions and motivations that embolden disadvantaged groups and individuals to engage in behavior that ultimately effects concrete social change.

\section{Empowering interaction partners and $3^{\text {rd }}$ parties}

Humans have a strong desire to be-and to be seen as-moral. This drive makes it difficult for advantaged individuals to acknowledge their privilege (and inequality more generally; Ellemers \& Van Den Toorn, 2015). Moreover, in intergroup contexts, members of advantaged groups are motivated to shape interactions such that they emphasize their preferred perspective (e.g., "all lives matter" in response to "Black lives matter"; Saguy, Dovidio, \& Pratto, 2008). These tendencies, coupled with the fact that most people explicitly endorse egalitarian values, mean that subtle (and often unintentional) manifestations of prejudice and discrimination will go unnoticed and unexamined by the (accidental) "transgressor" and other bystanders. In other words, the only person who will be aware of the prejudice is the target.

Haslam states, "to count perceived discrimination and ambiguous microaggressions as unqualified instances of prejudice is to subjectivize the concept. In addition to this subjectivity, the concept of micro-aggression extends the concept of prejudice by encompassing acts of omission and phenomena that reflect anxiety rather 
than hostility." Haslam is correct that these cases subjectivize the concept of prejudice, but he stops short of recognizing that there are objective consequences of microaggressions nevertheless (the exact kinds of consequences that psychologists are invested in understanding).

The failure to label, for example, a micro-aggression as prejudice does not mean the speaker will be shielded from feedback indicating that they have offended their interaction partner. If anything, the speaker may walk away from the interaction uncertain as to why the interaction did not go well. What will they do with this uncertainty? As psychologists, we have a reasonable hypothesis: in the absence of a better explanation, accidental "transgressors" are likely to attribute the negative arousal associated with uncertainty to their interaction partner (Schachter \& Singer, 1962; Vorauer, Main, \& O'Connell, 1998). Again, we see how uncertainty could contribute to increased avoidance of intergroup interactions, except this time from the perspective of the person who may have had no intention of being biased or expressing prejudice.

Once behaviors are collectively identified (or labeled) as prejudiced, people's strong desire to be moral may motivate follow-up behavior to redress (accidental) transgressions and deeper inequities (Brown \& Cehajic, 2008; Brown et al., 2008; Cryder, Springer, \& Morewedge, 2012). In fact, marking discriminatory practices with labels indicating they are norm violations may also trigger bystanders' anger and engage $3^{\text {rd }}$ party norm enforcement (e.g., Fehr \& Fischbacher, 2004). This mechanism may draw in allies who might otherwise be unaware of these instances of prejudice and discrimination. Once $3^{\text {rd }}$ parties demonstrate their awareness and opposition to subtle prejudice, they can shift the collective norms for the entire community. For example, in a field experiment conducted in a high school, "referent" students (assigned to treatment based on their central positions in their school's various subgroups, within its complete social network) significantly changed their peers' perception of the norm that harassment was typical (Paluck \& Shepherd, 2012). Specifically, socially influential students took part in an anti-harassment seminar and then participated in a school-wide assembly in which they publically expressed their anti-harassment stances. From the beginning to the end of the school year, prescriptive norms regarding harassment changed significantly among those students who had frequent contact with the "referents" (relative to those who did not).

\section{Opening up institutional channels for change}

Finally, concept expansion may allow targets to seek justice through appropriate institutional channels. Our social institutions and the law move more slowly than our cultural understanding and sensitivity to more subtle manifestations of prejudice and discrimination. For example, labeling less severe forms of mental disorders as disorders makes it possible for patients to get treatment covered by their insurance. Similarly, labeling less prototypic prejudice as prejudice may make it easier for institutions-from HR offices to the justice system - to garner resources and funds to provide better support services to those in need.

\section{Conclusion}

In this commentary I have reviewed several potential benefits of concept expansion as it applies to prejudice and discrimination. Of course, this is not to say that 
I believe there are no costs associated with expansion. Rather, this commentary is specifically meant to challenge the suggestion that conceptual expansion causes more people to identify as victims, which then reduces their subjective sense of agency. As Haslam notes: "a serious appraisal of conceptual creep must reckon with these potential downsides." I agree with this statement. That said, I would counsel us to consider its potential benefits as well. 
Author's Note

I am very grateful to Susan Fiske, Mahzarin Banaji, and Carey Morewedge for helpful comments on earlier versions of this commentary. Address correspondence to Mina Cikara, Department of Psychology, William James Hall, Harvard University, Cambridge, MA 02138. Email: mcikara@fas.harvard.edu 


\section{References}

Bar-Anan, Y., Wilson, T. D., \& Gilbert, D. T. (2009). The feeling of uncertainty intensifies affective reactions. Emotion, 9, 123-127.

Becker, J. C., \& Wright, S. C. (2011). Yet another dark side of chivalry: Benevolent sexism undermines and hostile sexism motivates collective action for social change. Journal of personality and social psychology, 101(1), 62.

Berger, C. R. (1987). Communicating under uncertainty. In M. E. Roloff \& G. R. Miller (Eds.), Interpersonal processes: New directions in communication research (pp. 39-62). Newbury Park, CA: Sage.

Berger, C. R., \& Calabrese, R. J. (1975). Some explorations in initial interaction and beyond: Toward a developmental theory of interpersonal communication. Human Communication Research, 1, 99-112.

Berkman, E., \& Lieberman, M. D. (2009). Using neuroscience to broaden emotion regulation: Theoretical and methodological considerations. So- cial and Personality Psychology Compass, 3, 475-493.

Bonilla-Silva, E., \& Dietrich, D. (2011). The sweet enchantment of color-blind racism in Obamerica. The ANNALS of the American Academy of Political and Social Science, 634(1), 190-206.

Bradac, J. J. (2001). Theory comparison: Uncertainty reduction, problematic integration, uncertainty management, and other curious constructs. Journal of Communication, 51(3), 456-476.

Brown, R., \& Cehajic, S. (2008). Dealing with the past and facing the future: Mediators of the effects of collective guilt and shame in Bosnia and Herzegovina. European Journal of Social Psychology, 38(4), 669.

Brown, R., González, R., Zagefka, H., Manzi, J., \& Čehajić, S. (2008). Nuestra culpa: collective guilt and shame as predictors of reparation for historical wrongdoing. Journal of personality and social psychology, 94(1), 75.

Camerer, C., \& Weber, M. (1992). Recent developments in modeling preferences: Uncertainty and ambiguity. Journal of risk and uncertainty, 5(4), 325-370.

Cikara, M., \& Paluck, E. L. (2013). When going along gets you nowhere and the upside of conflict behaviors. Social and Personality Psychology Compass, 7(8), 559571.

Cohen, G. L., \& Steele, C. M. (2002). A barrier of mistrust: How negative stereotypes affect cross-race mentoring. In J. Aronson (Ed.), Improving academic achievement: Impact of psychological factors on education (pp. 303-327). San Diego, CA: Academic Press.

Crocker, J., Major, B., \& Steele, C. (1998). Social stigma. In. DT Gilbert, ST Fiske, \& G. Lindzey. The handbook of social psychology, 2, 504-553.

Cryder, C. E., Springer, S., \& Morewedge, C. K. (2012). Guilty feelings, targeted actions. Personality and Social Psychology Bulletin, 38(5), 607-618.

Davis, C. G., Nolen-Hoeksema, S., \& Larson, J. (1998). Making sense of loss and benefiting from experience: Two construals of meaning. Journal of Personality and Social Psychology, 75, 561-574. 
Devine, P. G., \& Vasquez, K. A. (1998). The rocky road to positive intergroup relations. In J. L. Eberhardt \& S. T. Fiske (Eds.), Confronting racism: The problem and the response (pp. 234-262). Thousand Oaks, CA: Sage.

Dixon, J., Levine, M., Reicher, S., \& Durrheim, K. (2012). Beyond prejudice: Are negative evaluations the problem and is getting us to like one another more the solution? Behavioral and Brain Sciences, 35(06), 411-425.

Dovidio, J. F., Gaertner, S. L., \& Saguy, T. (2009). Commonality and the complexity of "we": Social attitudes and social change. Personality and Social Psychology Review, 13(1), 3-20.

Dovidio, J. F., Gaertner, S. L., \& Saguy, T. (2015). Color-Blindness and Commonality Included but Invisible?. American Behavioral Scientist, 0002764215580591.

Ellemers, N., \& Barreto, M. (2009). Collective action in modern times: How modern expressions of prejudice prevent collective action. Journal of Social Issues, 65(4), 749-768.

Ellemers, N., \& Van der Toorn, J. (2015). Groups as moral anchors. Current Opinion in Psychology, 6, 189-194.

Fehr, E., \& Fischbacher, U. (2004). Third-party punishment and social norms. Evolution and human behavior, 25(2), 63-87.

Festinger, L. (1954). A theory of social comparison processes. Human relations, 7(2), 117-140.

Fromm, E. (1947). Man for himself: An inquiry into the psychology of ethics. New York: Rinehart.

Gray, K., \& Wegner, D. M. (2009). Moral typecasting: Divergent perceptions of moral agents and moral patients. Journal of Personality and Social Psychology, 96, 505-520.

Greco, V., \& Roger, D. (2003). Uncertainty, stress, and health. Personality and Individual Differences, 34(6), 1057-1068.

Gudykunst, W. B. (1995). The uncertainty reduction and anxiety-uncertainty reduction theories of Berger, Gudykunst, and associates. In D.P. Cushman \& B. Kovacic (Eds.), Watershed research traditions in human communication theory (p. 67100). Albany: State University of New York Press.

Hogg, M. A. (2007). Uncertainty-identity theory. In M. P. Zanna (Ed.), Advances in experimental social psychology (Vol. 39, pp. 69-126). San Diego, CA: Academic Press.

Kramer, R. M., \& Wei, J. (1999). Social uncertainty and the problem of trust in social groups: The social self in doubt. The psychology of the social self, 145-168.

Lieberman, M. D., Inagaki, T. K., Tabibnia, G., \& Crockett, M. J. (2011). Subjective responses to emotional stimuli during labeling, reappraisal, and distraction. Emotion, 11(3), 468.

Lopes, L. L. (1987). Between hope and fear: The psychology of risk. Advances in experimental social psychology, 20(3), 255-295.

Paluck, E. L., \& Shepherd, H. (2012). The salience of social referents: A field experiment on collective norms and harassment behavior in a school social network. Journal of personality and social psychology, 103(6), 899.

Pennebaker, J. W. (1997). Writing about emotional experiences as a therapeutic process. Psychological Science, 8(3), 162-166. 
Cikara

Pennebaker, J. W., \& Graybeal, A. (2001). Patterns of natural language use: Disclosure, personality, and social integration. Current Directions in Psychological Science, 10(3), 90-93.

Saguy, T., Dovidio, J. F., \& Pratto, F. (2008). Beyond contact: Intergroup contact in the context of power relations. Personality and Social Psychology Bulletin, 34(3), 432-445.

Saguy, T., Tausch, N., Dovidio, J. F., \& Pratto, F. (2009). The irony of harmony intergroup contact can produce false expectations for equality. Psychological Science, 20(1), 114-121.

Schachter, S., \& Singer, J. (1962). Cognitive, social, and physiological determinants of emotional state. Psychological review, 69(5), 379.

Sorrentino, R. M., \& Roney, C. J. (1986). Uncertainty orientation, achievement-related motivation, and task diagnosticity as determinants of task performance. Social Cognition, 4(4), 420-436.

Stephan, W. G., \& Stephan, C. W. (1985). Intergroup anxiety. Journal of Social Issues, $41,157-175$.

Suls, J., \& Wheeler, L. (2000). A selective history of classic and neo-social comparison theory. In Handbook of social comparison (pp. 3-19). Springer US.

Tabibnia, G., Lieberman, M. D., \& Craske, M. G. (2008). The lasting effect of words on feelings: Words may facilitate exposure effects to threat- ening images. Emotion, 8, 307-317.

Tropp, L. R. (2003). The psychological impact of prejudice: Implications for intergroup contact. Group Processes \& Intergroup Relations, 6(2), 131-149.

Ufkes, E. G., Calcagno, J., Glasford, D. E., \& Dovidio, J. F. (2013). A dual pathway approach to understanding how common ingroup identity undermines collective action: Explaining decreased collective action among minority group members via group-based anger and efficacy (Unpublished manuscript). University of Twente, Enschede, Netherlands.

Van Zomeren, M., Postmes, T., \& Spears, R. (2008). Toward an integrative social identity model of collective action: a quantitative research synthesis of three socio-psychological perspectives. Psychological bulletin, 134(4), 504.

Vorauer, J. D., Main, K. J., \& O'Connell, G. B. (1998). How do individuals expect to be viewed by members of lower status groups? Content and implications of metastereotypes. Journal of personality and social psychology,75(4), 917.

Wilson, T. D., \& Gilbert, D. T. (2008). Explaining away: A model of affective adaptation. Perspectives on Psychological Science, 5, 370- 386. 